\title{
An Analysis of Movies based on World War II: A Qualitative Content Analysis of a Romantic-tragedy and a Historical Period Drama
}

\author{
Jindal N, Narula S*and Srivastava AA
}

Amity School of Communication, Amity University, Madhya Pradesh, India

\begin{abstract}
The paper aims at understanding two movies rooted in World War II, based on their genre, content, understanding of historical, institutional contexts prevalent in the society during World War II. The details that the paper has aimed at studying pertain to Auschwitz concentration camps. Furthermore, the paper will also try to comprehend the variety of ways in which a film creates meaning. The study takes up a discourse analysis of the two movies- a romantic tragedy Colette and a historical period drama Schindler's List.

What makes it relevant and expedient is the fact that the movies in discussion have both been made out of experiences of the World War and more importantly, Auschwitz (Concentration Camps). This has given a perspective to the analysis and has fittingly created a realm of discussion and discourse on the theme. What is even more significant to note is the fact that both the films are inspired from true events that happened at the concentration camps, in their own time.

Colette is inspired from a work of art titled A Girl from Antwerp written by Arnost Lustig, as an autobiographical novel from his experiences in a Nazi Concentration Camp. Lustig was a renowned Czech-Jewish author, and this novel is an important piece of work in the history of Czech literature.

Schindler's List is an American historical period drama, inspired from Thomas Keneally's novel Schindler's Ark. The literature is an inspiration from a story of Oskar Schindler, a German businessman who saved the lives of over a thousand Polish-Jewish refugees from frequent genocides at the Nazi concentration camps. The paper aims at studying the content of the two different genres under the same theme and topicality. It aims at coming to an understanding of Auschwitz, the lives therein and the trail it left.
\end{abstract}

Keywords: Movies; Drama; Socio-cultural

\section{Objectives}

- To study the following aspects of the movies in discussion-

- Conceptualization-interpretation of the script in terms of theme, genre, purpose, style, mood and overall structure;

- To study the socio-cultural scenario of the two movies, as they are portraying the World War II era;

- To study the treatment of the theme;

- To understand the movie from the directors' point of view;

- To make comparisons of the light in which Auschwitz concentration camps have been showed in the two movies.

\section{Introduction}

\section{Content, treatment and direction}

The content and treatment of a movie is understood as the manner in which the story or plot is developed. Treatment determines how the story has to be structured. After the basic structure is developed, an outline of the story is created scene-by-scene. There has to be clarity about the structure or the plot that one aims to develop from the story at hand. This portion is termed writing screenplay and the writer cannot hurry into this. He or she has to devise a plan of writing screenplay, after the plot is clear. The writer and director can either be the same person or different. Either the story goes to the director or the director comes to the story. In any of the one case, the treatment of the movie depends upon how the entire idea is framed.

To discuss the movie from the director's point of view, one must first try to understand the director's drive behind the work. His or her vision, thought processes and determination to have come up with the work he or she did. It's his or her vision and force that pulls the film together. Even before the project begins, the director has the ability to create word pictures in front of him or her, from the script he or she has been handed to work upon. In case the directors work with the writer to develop the script, he or she starts creating visions for the movie in the early phase itself. The director is the leader who takes care of the project, the cast and crew and minute details from beginning to end.

With regards to direction, all directors have their own levels of interest in getting involved in the camera work. A lot of directors like to take care of the camera work by telling the camera man where to put the camera, what lens to use and what movement to put the camera into depending upon the shot. The director will keep going with takes until the desired result is achieved. The music or background score for the movie is finalized by director too. Since, he or she is the person whose vision has gone into the movie; the director knows best what music will suit the characters and the plot best. The composition is

*Corresponding author: Narula S, Deputy Director, Amity School of Communication, Amity University, Madhya Pradesh, India, Tel: 9560452625 E-mail: suminarula@gmail.com

Received August 04, 2015; Accepted October 19, 2015; Published October 29 , 2015

Citation: Jindal N, Narula S, Srivastava AA (2015) An Analysis of Movies based on World War II: A Qualitative Content Analysis of a Romantic-tragedy and a Historical Period Drama. J Mass Communicat Journalism 5: 277. doi:10.4172/21657912.1000277

Copyright: $\odot 2015$ Jindal N, et al. This is an open-access article distributed under the terms of the Creative Commons Attribution License, which permits unrestricted use, distribution, and reproduction in any medium, provided the original author and source are credited. 
taken care by a music director but it is the director's final verdict that clears the music for the movie.

Hence, the content treatment and direction of a movie make it a cohesive whole. These are tasks that are put together by a team with the guidance of the director mostly. The best amalgamation of these elements ensures the success of a movie.

\section{Colette (in 2013): Director: Milan Cieslar}

Content and treatment: Colette has been filmed on the novel A Girl from Antwerp by Pulitzer Prize nominee Arnost Lustig. The backdrop of the autobiographical novel is the Auschwitz concentration camp during World War II. Lustig the Czech-Jewish author is known for his novels, short stories, plays and screenplays. The author was born in Prague during World War II and was sent to the Theresienstadt concentration camp in 1942, followed by the Auschwitz concentration camp and Buchenwald concentration camp. He escaped in 1945 from a train bound to Dachau concentration camp. His autobiographical work is inspired from his experiences of being a war prisoner. What makes this work different from other movies about life in concentration camps is the fact that it is a dramatic story of young lovers. Colette is a narrative that jumps back and forth from 1978 in New York City to 1945 in Auschwitz camp, and begins as a narrative from Colette.

It is July 1943, Concentration Camp- Birkenau. Vili Feld (played by Jirí Mádl) at the camp, where a train carrying new inmates arrives where he sees Colette (played by Clémence Thioly) and saves her life by advising her to tell her skills as a seamstress and that she has been healthy always. Vili is runner at Auschwitz and transports clothing and belongings of recently arrived prisoners at the concentration camp. Colette is initially sent to the mines, and the camp commandant orders her back to the camp to work as a sorting worker. The camp commandant grows a liking for Colette and asks her for sexual favours, which is very common in the concentration camp. This to the extent that he stops her from being sterilised and continues to force her to do him sexual favours [1].

Anybody who tries to steal anything while transporting goods to the sorting room is punished by lashes, some of them shot then and there. Vili becomes a pick of the kapos to transport eatables, perfumes and other material among kapos at the camp. This also helps Vili and Colette to meet every now and then. More than that, the kapo supervising the male prisoners helps to get Vili appointed as the Registrar at the camp.

While Vili is a transporter, he saves precious material to help him escape the camp later, as time would favor. Colette also saves gems, stones, money and jewelry while sorting, for the same purpose. It is when Vili is appointed as a Registrar that he plans his escape with Colette by bribing the officials who transport logs in and out of the concentration camp.

As fate would have it, Colette could not make it to the escape plan, and Vili drops his idea. Instead two other prisoners plan to escape, and are later killed by the commandant, who finds out about the escape plan. It is later when Germany is towards a defeat that the camp has to be evacuated and the prisoners of war are taken out and the camp commandant is killed by the Russian army. Vili goes to Prague and gets into a constant effort to find Colette, till he receives a letter saying that she was dead.

The movie comes to the present day New York City, 1978, where Vili's son is in love with Colette's daughter and the protagonists meet for the first time after 1945.
The movie is yet another work on showing the facts about life in a concentration camp. Apart from this, and the love interests of the protagonists, it also shows how Colette is caught in an awful situation where she is required to sexually please the German official commandant at the camp. Colette's story is just emblematic of similar other stories at the concentration camp where prisoners were required to please senior officials. The movie is like many others about the Auschwitz concentration camp and the kind of life people were made to lead there.

The background score is a commendable effort by Icelandic composer Atli Örvarsson, and the performance of Czech musicians is admirable, keeping the music perfectly emotionally balanced without it becoming overwhelming. There is a central European essence to the music, which is similar to another movie in discussion- Schindler's List, and also the Pianist. Some critics have termed the music as Örvarsson's version of Schindler's List, only with its sense of intimate, intense beauty. The music is impressively theatrical, heavy on the strings, and stimulating.

Direction: About the movie in discussion here, director Milan Cieslar, a Czech film and television director, has displayed the romance of two young lovers in the light of Auschwitz concentration camp, with the aim of showing this one case as emblematic of many others that would end up the same way, during the times of war or afterwards.

The film has been shot in English and Czech, and based on an autobiographical novel by Arnost Lustig. The movie released in the year 2013 is relevant to the war times and the concentration camp, and it has been made compelling by the background score by Atli Örvarsson [2]. The use of lighting effects gives a fine reflection of the years in discussion (1943 and 1945-Auschwtitz, 1978-New York City). The movie sets have been kept simple to offer it the appropriateness that is required. The choice of cast and crew adds to the authenticity of the concept and the treatment of the movie. The light in which the extermination camp has been shown, matches the audiences' understanding of what they have known or read about the same.

The creation and portrayal of characters to suit their backgrounds in the movie has been done in a manner that quantifies the years in showcase. Furthermore, the fact that the movie has been shot in color, and has kept the essence of the epoch adds to its simplicity and lends credibility to it.

The director has been able to do justice with the plot, however, it seems too constricted to only the love life and sufferings of two people, and hence the director has tried to justify that with the name of the movie. Hence, the movie fails to broaden our perspectives, knowledge and comprehension of the concentration camp anywhere beyond the lives of the protagonist and her lover. Therefore, it remains to just being Colette and not more.

\section{Schindler's list (in 1993): Director: Steven Spielberg}

Content and treatment: Speilberg's Schindler's List is a cinematic adaptation of Australian novelist Thomas Keneally's Booker-prize winning novel Schindler's Ark [3]. Keneally was inspired by a concentration camp (also known as the holocaust) survivor Poldek Pfefferberg.

The novel describes the experiences of Pfefferberg, a PolishAmerican who was recruited to the Polish army and after the defeat of Poland and its partition between Nazi Germany and the Soviet Union, was imprisoned at Plaszow near Krakow. He met Oskar Schindler, a 
German industrialist, spy and a member of the Nazi party during this time, who was in the process of taking over an enamelware factory that had been seized from the Jews. This factory was where Oskar Schindler hired Pfefferberg and as many as 1200 Jews, which later came to be known as Schindler's Jews.

Keneally's novel is an account of not just Pfefferberg's but various other eye-witnesses and war prisoners' telling tales. The novel brings to surface, the various horrors of the holocaust and atrocities of Hitler. At the same time, Keneally has taken into consideration that the novel doesn't turn out to be melodramatic. This essence is seen in Spielberg's Schindler's List, which is no less compelling.

It begins in the year 1939. The Polish have been defeated by the German army, and the Jews are required to register all their family members and over 10,000 Jews move to Krakow every day from the countryside. A Jewish Council is created out of elected members to draw lists of these Jewish workers, their food and housing. Oskar Schindler hires a Jew Iztak Stein to find investors for an enamelware company he wishes to start, also because Stein managed the accounts for one such company. This goes on as an aside, while on the bigger front 1941, Jews from Krakow and surrounding areas are asked to move to a ghetto established near Vistula River.

The Jewish are being transported to the concentration camp and Stein arranges for a lot of them to be instead transported outside the ghetto to work for Schindler's factory, and does that by getting their fake skill-certificates created, on the spot. These non-skilled people are then trained at the factory Schindler has just bought to turn them into skilled metal polishers and other requisite works.

He sends invites to the officials of the German army for a party to launch his exquisite silverware created chiefly for the use of the German army. The party is thrown with the best alcohol- cognac, wine, champagne; cigars, and lavish, sumptuous food, not to mention, female escorts. Meanwhile, the forced labour camp in Plaszow has its commandant who hires a Jewish girl as his domestic help. There are also instances of her exploitation which is a regular phenomenon in the camp. To add onto the labour workforce, there is a liquidation of the ghetto every now and then. This leaves many Jews misplaced, many dead, and others, fighting for survival. It leaves all work and industries hauled. Schindler's is deeply perturbed by the mass-killing and gets a luncheon arranged with the Plaszow camp commandant, who prompts him to shift his factory from the ghetto to the Plaszow camp.

Towards the climax, the train carrying women and children when accidentally gets redirected to Auschwitz-Birkenau, Schindler bribes the commandant of Auschwitz- Rudolf Hoss to attempt their release. Jewish workers are allowed to observe the Sabbath at the factory. The movie is about how Schindler spends most of his fortune bribing the Nazi officials to save his Jewish workforce and keep them alive. It is in 1945 that he runs out of his fortune only to surrender to the Americans as Germany is defeated at the end of the war.

Schindler's Jews give a signed statement to him substantiating his role in their survival with a ring engraved with a quote- "Whoever saves one life saves the world entire". Even here, Schindler breaks down feeling helpless that he could have saved more Jews, only he had not spent his wealth worthless.

Schindler ensures that he hires Jews for his factory to save them from getting transported and killed at Auschwitz. However, his major concern was to earn money, and hire Jews as they could be hired at lesser salaries. Schindler initially wasn't truly concerned about saving his Jewish workforce, but towards the end, everything else had taken a back seat while Schindler puts in all efforts to save the Jew workers from getting murdered at the Nazi extermination camp. The film is a spectacular portrayal of the kind of arrangements he makes to create the 1200 person list to be saved from Auschwitz. It is these independent Jews who later came to be known as have set up the new Israel, as we know now [4].

The soundtrack is given by John Williams, and comes out as typically European, subtle at places, and melodramatic when required. It carries the purpose of a major symphony composition, with reminiscent violin solos by renowned violinist Itzhak Perlman. Sentimentality and pomposity have been married very well by John Williams' and Itzhak Perlman's works. The music derives its emotion from the events that it aims to depict, which makes it plausible. The emotionality of the holocaust has well been depicted by the soundtrack, making it much easier for the audiences to comprehend the incidences. Amidst all the bloodshed and gory killing, the movie still speaks loud of survival and hope.

Direction: Steven Speilberg's Schindler's List has been adapted from Australian novelist Thomas Keneally's novel Schindler's Ark (in 1982). The movie was released in the year 1993 and shows the ear in discussion (beginning 1939 to 1945) very aptly, owing to its direction. Another fact about the movie that not many are aware of is that Speilberg was also influenced by the 1985 documentary Shoah, in making Schindler's List the way he did. Picking up from that the idea of not using steady cameras for the shooting and sticking to simple and basic shots added to the credibility of the era that the movie wanted to show.

Furthermore, the movie was shot in black and white and Speilberg could keep up with his idea and promise of making it in a documentary form. From the direction point of view, the movie fulfils both the approaches of that of a movie and a documentary. It lends an intense character to the plot and touches the ideal points in the storyline. Whether it is the Auschwitz concentration camp, or the streets of Germany, or the ghettos, the portrayal has been able to throw true light on the socio-cultural conditions; the way people lived and were killed. The element of light has been aptly utilized in the movie in giving the audiences the understanding of the social setup, the period and the people shown therein [5].

Speilberg, as is known, has put in effort into researching for the movie, dictated his movie on the terms of a documentary and even when the project started in early 1992, the sets were created with just the right precision. The cast matched with their original counterparts, whether it was Oskar Schindler (Liam Neeson), Itzhak Stern (Ben Kingsley) Amon Goeth (Ralph Fiennes) or Poldek Pfefferberg (Jonathan Sagall).

Music composition is given by John Williams, who has worked with Speilberg in a lot of projects, and believed that the music for this one was produced effortlessly and spontaneously. As simple as it is, the background score also depicts the scenes pertinently, rather enhances the overall impact of the movie.

\section{Analysis: Similarities and Dissimilarities in Content ${ }^{*}$}

One fact that comes down as a similarity in the two movies is that both are adaptations of literary works- novels that were written from personal experiences of the Auschwitz concentration camp.

\section{Colette}

While Colette is an autobiographical work by Arnost Lustig, also, 
the male lead in the movie, describing his romance with Colette and how the dire circumstances couldn't stop their love interests. The movie, shows in forceful light, how the concentration camp changes the two individuals and when they meet at a later stage in life, they come off as satiated beings, with scars on their souls, to carry for life. The movie shows how the two transformed individuals might not want to come together even as the circumstances might have permitted.

Colette did not want to reunite with her lover Vili after the war ends, as she delivers the child she was carrying from her sexual abuse at the concentration camp. It dawns on her that she would want to love the child as her own without making Vili a part of that life. That Vili accepts it and notes their experiences in a literary form, is an evidence of him moving on and accepting the fact that the war had changed the two young lovers, as they had grown old [6].

Colette is about the life in the Nazi camp but is concentrated majorly on the experiences of two individuals and few other people closely connected to them while they were at Auschwitz. It is about how these two individuals grow to be different individuals when they actually get to meet years after the war is over and when their respective children come together to get married. There are not many instances to add to our comprehension of the social milieu of that time, other than what is shown in the concentration camp. Colette is about survival and sanguinity.

\section{Schindler's list}

Schindler's List is based on a biographical work titled Schindler's Ark by Thomas Keneally. Keneally's meetings with the holocaust survivor Poldek Pfefferberg, who was closely related to Oskar Schindler, and the research and interviews with other survivors led to the literary work.

The movie portrays the efforts of one otherwise corrupt man to save the lives of Jews from the Auschwitz concentration camp. Oskar Schindler, a German businessman, spy and a member of the Nazi party takes over an enamelware factory where he gets Jews to work for him, as they cost less, for enameling silverware and make shell casings (that wouldn't fire!). His aim was to create a safe living and work environment for his Jew workforce, and save them from being killed in the concentration camp at Auschwitz.

The movie is a bright effort in showing the buoyancy and tact of Schindler as a businessman, his use of resources, contacts and his influence in getting work done. The socio-cultural milieu of Germany during the time and the dictatorship of the warlords is also the prime focus of the movie, as it does not restrict itself to showing the Auschwitz concentration camp. The movie moves out of the camp and takes us to the streets of war-torn Germany. It shows how the feudal lords governed not only the Nazi camp but had a lot of control in the way the Jews were treated during those times. There are small incidences that help one understand and make sense of the German empire during war.

\section{Other comparisons}

The fact that both Colette and Schindler's List are about the Auschwitz concentration camp does not make the two movies any similar. The only aspect that however, is seen as similar is the concentration camp and the lives Jews were made to live there. In that too, the two movies show us varied aspects of the extermination camp that make the two dissimilar. The content of the two movies in discussion is unrelated, even when the background is similar, and based on war-torn Germany and the concentration camp.

While Colette is about a romance that was to dawn on Colette and Vili in the backdrop of the Auschwitz extermination camp, and it shows life inside of the camp; Schindler's List is about a German businessman who was to spend his entire fortune on saving his Jewish workforce, and it moves outside of the periphery of the Nazi camp.

Colette has portions showing the brutality that was administered upon the prisoners of war, while Schindler's List is subtle in showing how war affected people, the prisoners, the ones living in the ghetto and other workers. With this said, both the movies are still subtle in showing the brutality administered on the prisoners of war (PoW), and even people living in the ghettos. Other similar works, especially documentaries (for instance, Night and Fog) have taken a completely true stance at the unkindness and maddening cry during the world war. The ghettoization of lives has a near true depiction in the movie Schindler's List. Besides, the extravagant lives of German officials and industrialists are also delineated righteously in the said movie. The similarity between the two movies also lies in this particular portrayal, wherein the lavish ways of living of German officials in the movie Colette are shown as more or less similar to that of Schindler's List.

The two movies have been taken in very different light even when the premise somehow appears to be same. Auschwitz, war-tattered nations, the concept of ghettoization, the killing of Jews are the common events. However, even with these huge familiar events in the two movies, they are completely different with genres set apart.

\section{References}

1. Atchity K, Wong C (2003) Writing Treatments That Sell: How to Create and Market Your Story Ideas to the Motion Picture and TV Industry. (2ndedn), Paperback.

2. Lumet S (1996) Making Movies. (1stedn), Paperback.

3. Keneally T (1982) Schindler's Ark. (1stedn), Paperback.

4. http://www.mzv.cz/washington/en/culture_events/news/new_film_colette_ reveals_love_s_power.html

5. https://www.jewishvirtuallibrary.org/jsource/Holocaust/Schindlerslist.htm

6. http://www.theguardian.com/film/2015/may/15/son-of-saul-review-anoutstanding-excoriating-look-at-evil-in-auchwitz 